- Every two years a lecture is given in memory of Wilfred Fish, First President of the General Dental Council.

- The text of this lecture is printed in the BDJ.

- This year the lecture was given at the GDC 20 March, 2002.

\title{
Wilfred Fish Lecture
}

\author{
M. Brazier ${ }^{1}$
}

It is a great honour to be invited to deliver this lecture in memory of Sir Wilfred Fish, first President of the General Dental Council. I am only too well aware of my unfitness for the task: my experience of dentistry is limited to the dental chair; my knowledge of dental law is virtually nil. I trust that Sir Wilfred would not disapprove. His contribution to dentistry was enormous; his labours ensured that dentistry received both the independent recognition it merits and its own regulatory framework, freed from any sort of subservience to medicine.

Let me move to the subject of my lecture 'The tooth fairy in the dock'. What, you may ask has that apparently innocuous creature done to land herself (or is it himself) in the dock? Her conduct leaves her vulnerable to at least two 'charges'. She is complicit in the illegal practice of dentistry, inciting unwary parents to break section 38 of The Dentists Act 1984 by pulling out that irritating wobbly tooth. She 'trades' in human body parts, paying, I believe, an extortionate sum per tooth these days, (as much as $£ 2$ for difficult milk teeth). She is, in short, an irredeemable criminal; and crime is what I want to talk about tonight.

The evidence of the rise and rise in civil litigation against the NHS is well documented. Last year the National Audit Office reported that $£ 2.6$ billion was set aside to meet existing claims. A further £1.6 billion was estimated as needed to meet likely, potential claims. ${ }^{1}$ Less well publicised is the growing number of criminal prosecutions brought against doctors, and less often other health professionals. This actual rise in pros-

The text of this lecture has previously been published in the GDPA. 2002;14(6).

${ }^{1}$ Margaret Brazier, Professor of Law, Centre for Social Ethics and Policy (CSEP), Manchester School of Law, University of Manchester, Oxford Road, Manchester M13 9PL

Email:Shirley.Tiffany@man.ac.uk ecutions should be explored in the context of an even greater clamour that doctors ought to be punished for what they have done or are alleged to have done. I confessed earlier to my ignorance of dentistry. Let me apologise again for my focus on doctors. My alternative title to this lecture was:

\section{Thank God, I'm not a doctor}

I want to consider four questions:

1. What sort of circumstances justify invoking the criminal law to punish a doctor whose conduct results in death or serious injury?

2. What motivates the passionate demand that pathologists who retained human body parts without the knowledge or consent of the family of the deceased be prosecuted?

3. Why have medical practitioners fallen so far from their lofty pedestal to become apparently so much distrusted?

4. Are dentists next in line?

\section{CRIMINAL NEGLIGENCE?}

Unlike some other legal traditions (including Scotland) the common law in England has never treated negligence, even gross negligence, as a crime per se. ${ }^{2}$ Legislation has gradually enlarged the list of specific conduct where carelessness alone is punishable by the state. Careless driving is the pre-eminent example. Negligence in the context of health and safety at work offers another example of the state determining that non-deliberate wrongdoing merits society's condemnation. It is not sufficient to provide a civil remedy in monetary compensation to redress the wrong done to any individual injured by that lack of care. Indeed the relevant crime may be committed without any actual injury having been caused. The criminal law is used to deter careless conduct, to reduce the

...the rise in civil litigation against the NHS is well documented. Last year the NAO reported that $£ 2.6$

\section{billion was set aside to meet existing claims}

incidence of personal injury. No statute, as yet, penalises negligent healthcare or surgery without due care or attention.

The criminal law is likely to intervene to place the doctor in the dock in two principal scenarios. Where a patient claims that what was done to her was done without a valid and real consent, the doctor (or dentist) may, in theory at least, 
face prosecution for assault. Should a patient die, a grossly negligent doctor may be charged with manslaughter. The past decade has seen a range of medical (mis)conduct prosecuted as manslaughter. I shall focus on four cases.

In 1992, Drs Saha and Salim ${ }^{3}$ were convicted and imprisoned after a prisoner died in police custody. The deceased had a history of drug abuse. He became agitated and requested a tranquilliser. Without examining him fully or reviewing his medical history, the accused between them prescribed a cocktail of sedative drugs in dosages several times the recommended maximum. I suggest that their conduct exhibited a cavalier disregard for the welfare of their patient. It truly constituted misconduct.

In 1994 a GP inadvertently prescribed beta-blockers for a patient with asthma. The patient suffered a broncho-spasm and died. A careful history would have prevented the error. Asthma is a known contraindication for beta-blockers. Death following broncho-spasm is a foreseeable possibility, but a rare event. The doctor made a terrible mistake. He then compounded his error, falsifying his records. He was sent to gaol, not for causing his patient's death, but for attempting to pervert the course of justice. ${ }^{4}$

Finally there are the two index cases, the case involving two junior doctors, Drs Sullman and Prentice, and the prosecution of Dr Adomako. The cases were heard on appeal together. The facts are very different.

Let us consider Drs Sullman and Prentice first. A 16-year-old boy was admitted to Peterborough General Hospital for his monthly chemotherapy. He had suffered from leukaemia since the age of four. His regime required that that month he received two drugs - vincristine (to be administered intravenously) and methotextrate (administered intrathecally). Dr Prentice was a pre-registration house officer; Dr Sullman a house officer. Neither had ever administered such drugs before, nor had they received any relevant train-

The doctor made a terrible

mistake. He then

compounded his error, falsifying his records. He was sent to gaol, not for causing his patient's death, but for attempting to pervert the course of justice ing. The drugs were brought down to the ward on a trolley. Dr Prentice asked Dr Sullman to supervise him in administering the lumbar puncture. Dr Sullman believed that he was just supervising the procedure itself. Dr Prentice injected vincristine into the boy's spine. The boy died some days later in agony. Careful reading of the labels on the vials of both drugs would have indicated the proper route of administration, though not necessarily the disastrous effect of administering vincistine intrathecally. Both doctors were convicted of manslaughter, albeit the judge told them 'you could have been helped more than you were helped' - 'You are far from being bad men'. They were guilty, the trial judge said, of momentary recklessness, but that sufficed to make them criminals.

Dr Adomako was an anaesthetist. He had worked as a locum for 15 years, rarely staying more than a few months in any job. His command of English was poor. In the course of minor eye surgery he failed to notice for over four minutes that the tube carrying oxygen to his patient had become dislodged. His standard of care was said to be abysmal. Newspaper stories suggested he had left the theatre allegedly to make a cup of tea. This allegation was never proved.

Dr Adomako was also convicted of manslaughter. His appeal was consolidated into one hearing together with the appeals of Dr Prentice and Sullman. Their appeal succeeded. Dr Adomako's failed.

The Court of Appeal ${ }^{5}$ outlined the following test for gross negligence manslaughter.

1. Did the doctor (or dentist) show obvious indifference to the risk of injury to his patient?

2. Was he (or she) aware of the risk but decided (for no good reason) to run the risk?

3. Were efforts to avoid a recognised risk so grossly negligent as to deserve punishment?

4. Was there a degree of inattention or failure to have due regard to risks going beyond mere inadvertence.

At least one of these questions must be answered affirmatively before a doctor (or dentist) is convicted of manslaughter.

The appeal court ruled that in the cases of Drs Sullman and Prentice there was insufficient evidence of gross negligence. Dr Adomako's conviction was upheld. The appeal judges said he failed in 'his essential and...sole duty to see that his patient was breathing satisfactorily and to cope with the breathing emergency...his failure was more than mere inadvertence and constituted gross negligence of the degree necessary for manslaughter'.
Dr Adomako appealed to the House of Lords without success. ${ }^{6}$ The Law Lords neither reviewed the appeal court's four-part test of gross negligence, nor offered a helpful definition of their own merely saying:

You should only convict a doctor of causing death by negligence if you think he did something no reasonably skilled doctor would have done.

These manslaughter cases prompt as many questions as they answer. What is the rationale for punishing negligence, for criminalizing mistakes?

Alan Merry (a consultant anaesthetist) and Alexander McCall Smith (a law professor) argue in their superb book, Errors Medicine and the Law, ${ }^{4}$ that we should distinguish between two kinds of mistakes; errors which are not morally culpable and violations which involve deliberate wrongdoing, including deliberately unjustifiable risk-taking. Good people make terrible errors. Those who suffer as a result may have a proper claim for redress in terms of compensation. Society is not endangered by those errors, so it is not just to criminalise those individuals in error.

\section{They were guilty, the trial judge said, of momentary recklessness, but that sufficed to make them criminals}

They add a caveat. Society might judge that certain sorts of errors are so lamentably common that criminal law should be invoked to aid in deterring such errors. Merry and McCall Smith note that since the prosecution of Drs Sullman and Prentice, identical errors involving injecting vincristine into the spine has occurred on fourteen occasions. That tally is now fifteen after a further incident in Nottingham late last year. I understand that charges of manslaughter against the two doctors involved in the latest tragedy are being considered by the Crown Prosecution Service.

Applying a distinction between error and violation, the first two cases which I discussed earlier fall squarely into violation. The two police surgeons made no efforts to care for their prisoner-patient. They acted with total disregard for his welfare and their misconduct was not a simple error. The GP who falsified his records, whatever the nature of his prior mistake, deliberately broke the law. Drs Sullman, Prentice and Adomako remain the problem cases.

If $\mathrm{Dr}$ Adomako did leave the theatre for anything less than dire emergency he 
committed a violation; he deliberately abandoned his patient. If he did not, no doubt he was a dreadfully incompetent doctor. The appeal court, presumably answering their own question (3), decided he was so grossly negligent as to deserve punishment. By contrast, the two young house officers (Sullman and Prentice) were merely momentarily inadvertent. Merry and McCall Smith might ask whether even gross negligence deserves punishment if the accused himself is unaware of his incompetence.

In all three cases you may be musing about how those responsible for patient care allowed these events to come about. Why were two junior doctors left to administer such potent and toxic drugs untrained and unsupervised? How did a doctor as inadequate as Dr Adomako come to be working in the NHS? The root of both tragedies is a total systems failure. Punishment could be more readily justified if meted out to those ultimately responsible for that failure, or if soundly based on a coherent theory of deterrence. You might wish to argue that if the unfortunate Drs Prentice and Sullman had been convicted and gaoled, other junior doctors who later made exactly the same mistake would have been more careful? You may be attracted to Mary Childs's arguments that NHS Trusts, or indeed general dental practices, should face charges of corporate manslaughter. ${ }^{8}$

\section{The mortality at Bristol for open heart surgery on children under one was roughly double that elsewhere}

You may also wonder whether, if a theory based on deterrence justifies prosecution for manslaughter when the patient dies, should gross negligence causing injury short of death not also be punished. In Scotland, a dentist who used unsterilised equipment to cut corners and costs was convicted of culpable and reckless conduct, albeit no proof was offered that any patient did contract a blood borne disease. He was gaoled for three years for this offence and fraud. ${ }^{9}$ English law proceeds at a measured pace. Prosecutions in Wales where an elderly man died after the surgeon removed his only healthy kidney will provide further enlightenment.

What is not measured and maybe is not measurable, is public response to medical accidents, or to actual or perceived medical wrongdoing. Some of this is attributa- ble to a much more prevalent culture of retribution. A distinguished moral philosopher has commented: ${ }^{10}$

Accusing, condemning and avenging are part of our daily life

What drives such a culture of blame and vengeance? The history of events at Bristol and Alder Hey are well known. I will recap on the principal details. The Bristol Inquiry Report ${ }^{11}$ catalogues a series of fundamental errors in paediatric cardiac surgery at Bristol. The mortality at Bristol for open heart surgery on children under one was roughly double that elsewhere. The service was unco-ordinated and poorly managed. Valiant attempts by a consultant anaesthetist to persuade management to act rebounded on him. Managers effectively shot the messenger and did not listen to the message. Children died who might have survived elsewhere. Children were left disabled who might have thrived elsewhere. Three doctors, including the medical director were ultimately disciplined by the GMC. To my knowledge no prosecutions were brought nor has there been a sustained call that surgeons or managers should be prosecuted.

Almost as an aside in evidence to the Bristol inquiry, it emerged that in a number of cases after the death of a child in the course of paediatric surgery, his heart or other organs were retained. Commenting on the Bristol heart collection, ${ }^{12}$ Professor Robert Anderson noted that the 'best' and largest heart collection was held at Alder Hey Hospital in Liverpool. An inquiry into Alder Hey ${ }^{13}$ confirmed the Professor's diagnosis of the largest collection. The Alder Hey Report revealed a practice of removing in many cases most of a child's organs, returning to her family what one family graphically described to me as a 'bag of skin'.

Nor does the story end at Alder Hey. Removal and retention of organs at postmortem for purposes of medical education and research was for years a routine practice. ${ }^{14}$ Retention was practised in many instances with no consent, in others with a consent I would describe as largely mythical. There was a form signed, but signed in ignorance of what was truly proposed, and in some cases signed in circumstances where the purported consent could not be seen as genuinely voluntary. For families their perception of what was done to them

\section{Children died who might}

have survived elsewhere. Children were left disabled who might have thrived elsewhere and their relatives is that it was criminal. I have heard so often the following sentiments expressed:

They robbed me of most of my child's body.

They stole my husband's brain.

My daughter was mutilated - what happened was barbaric.

We were deceived - it was fraud.

\section{...in no case will a}

\section{prosecution be brought by the Crown in relation}

\section{to organ retention}

Let me say now that the overwhelming majority of relatives whom I have met in connection with my work on organ retention are eminently sensible and courteous people. Many are absolutely clear that, had they been asked to authorise the retention of their relative's organs to promote medical research or education, they would have agreed. A number would have been prepared to forgive and forget what happened in the past if it could be shown that research or teaching had produced benefits for others, rather than as happened in Liverpool a stockpile of organs, foetuses and stillborn infants simply amassing in cellars across the city. As events have unrolled forgiveness is a long way away and many, many families continue to demand that pathologists be punished.

I understand that the Crown Prosecution Service has advised that in no case will a prosecution be brought by the Crown in relation to organ retention. In the generality of cases, the uncertainty of the law and the period of time which has elapsed since the organs were removed are such that prosecution (the CPS says) will not serve the public interest. In relation to Professor Van Velzen, allegations in relation to alleged forgery of post mortem reports and removal of material and records from the University are to be investigated by Merseyside Police. Prosecution (even of Van Velzen) concerning the removal and retention of organs is highly unlikely. Relatives are outraged.

Understanding why no prosecutions are to be brought is relatively easy for the lawyer. ${ }^{15}$ The Human Tissue Act 1961, which, in part, governs removal of organs after hospital autopsy, is unclear and toothless. The Act permits removal of body parts for the purposes of medical education and research, where either the deceased has authorised the retention and use of her body parts prior to her death, or the hospital is satisfied, after such reasonable enquiry as is practicable, that neither the deceased nor 
any surviving spouse or surviving relative objected to such a course of action. The Act and its application in practice are liberally endowed with ambiguity. It speaks of removal of body parts. In practice what many relatives signed up to was described as removal of tissue. A form authorising removal of tissue was used to permit the removal of almost every organ in a child's body. The 1961 Act instructs hospitals to do what is practicable to assess whether objections to retention of body parts are present. It does not on its face mandate an explicit consent to donate organs. Hospital practice about what constitutes a reasonable effort to ascertain objections varied widely. The Human Tissue Act deals only with retention of organs after a 'consented' autopsy. Alas, in a number of cases the threat of a coronial autopsy was held over a family's head. They signed because they believed they had to. Deciding what the Act requires and when

\section{How do we understand}

\section{why Alder Hey sometimes}

\section{seems to have generated}

\section{greater outrage than}

\section{Harold Shipman's serial} killings?

the law was broken is hard enough. However, the Act provides absolutely no sanctions for its breach. No crime is committed in violating the Act.

Additionally to statute law, there are complex arguments about the common law and the disposal of bodies. ${ }^{16}$ Interfering with the rights of the executors to arrange the decent burial or disposal of the body may be an ancient common law crime. Returning a body virtually stripped of organs could be argued to constitute that crime. Equally arcane offences of causing a public nuisance, or wrongfully desecrating a corpse could be invoked. It all makes a field day for academic scholars and offers a fertile field to $\mathrm{PhD}$ students. None of which is any comfort to families.

How can we explain the overwhelming demand to punish conduct which may not be technically criminal, when there is a lesser demand to punish surgeons whose incompetence may have contributed to children's death in the first place? How do we understand why Alder Hey sometimes seems to have generated greater outrage than Harold Shipman's serial killings?

The answer lies, I believe, in two parts. Do people intuitively recognise a distinction between error and violation? The continued substandard practice of the Bristol surgeons is close to the borderline between the two, but as the Bristol Report itself accepts they believe they were doing their best. Bristol ${ }^{11}$ is not 'an account of bad people. Nor is it an account of people who did not care, nor of people who wilfully harmed patients'.

What went wrong in the operating theatre at Bristol was comprehensible, even if unforgivable if it was your child who died or survived with major disability. The revelations around organ retention focus on a sustained and deliberate practice, incomprehensible to many of the general public. What was done was not done by mistake. The ends that organ retention can serve in terms of education, research and audit are without doubt good ends. Alas, in so many cases those good purposes were not served. And in a number of high profile cases, the ends were bought with bad means, deception, coercion, half-truths. The result was that families feel that their child or their relative was treated as an object, a thing, a source of materials, not a person. They feel they were disregarded, treated as people of no importance. There are many, many other factors which go to explain the anger generated by organ retention. Deep seated grievance (often a fully justified grievance) that doctors abused their trust is a major factor. But what about Mr Shipman.

No other British doctor (or dentist) has (I pray) so grossly abused trust. Yet his behaviour is comprehensible. He was an evil man with no regard for his fellow men and women. He happened to be a doctor and used his position to fulfil his lust to kill. Had he been a caterer, he might have poisoned the canapés. Had he not had access to drugs, he might have resorted to cruder means. His conduct is straightforwardly criminal. He generates no great fears that he represents a pattern of conduct in medicine. It is the abuse of position that medical status grants the perpetrator which destroys trust.

Consider some notorious recent examples. A gynaecologist cavalierly says that he always removed ovaries from postmenopausal women regardless of whether or not the patient had consented to oopherectomy as well as hysterectomy the women and their husbands will be happier when they are on HRT! A surgeon declares himself the fastest gynaecologist in the South East. A GP deceives and intimidates women patients into allowing him to satisfy his sexual perversions. Such doctors not only breach their legal duty of care. They exhibit contempt for their patients, a total lack of care. A catalogue of truly awful abuse of trust by a tiny number of medical practitioners besets doctors, even though most doctors behave with absolute propriety and do their best in impossible conditions.
A catalogue of truly
awful abuse of trust by a tiny number of medical practitioners besets doctors, even though most doctors behave with absolute propriety and do their best in impossible conditions.

\section{WHITHER DENTISTRY}

You have your problems. In 1998 a dentist who continued to treat patients while suspended from practice was charged with assault. The Court of Appeal has recently ordered an HIV positive dentist to hand over his records rejecting his claim for privacy. Prosecutions for dental fraud have hit new records. The notorious $\mathrm{Mr}$ Garrett ${ }^{18}$ was successfully sued for battery by patients on whom he performed unnecessary and often risky treatment to inflate his profits. He injured his patients and defrauded the NHS. General anaesthesia in dental surgery has resulted in tragic deaths and successful prosecutions. A dentist in Leyland was prosecuted for manslaughter jointly with his anaesthetist when a child died in his surgery. Surprisingly, publicity around such dental 'scandals' remains relatively muted. I will suggest this state of affairs is unlikely to change for good and bad reasons (mostly bad).

Doctors suffer from a cruel paradox. For every media story condemning the demon doctor, there is another applauding the miracle-worker. Medicine (or certain medics) to a certain extent collude in such imagery and the angel who falls from grace swiftly becomes a demon. Dental successes are far less well broadcast. Dentistry has no counterpart to Lord Winston or Sir Magdi Yacoub. Treated (forgive me) as more run of the mill professionally, your patients and the public more readily accept your human fallibility.

Doctors must more frequently deal in those two highly charged areas of human life - death and sex. Dentists rarely do so in their professional life. As long as criminal prosecutions for negligence are confined to cases where the patient dies (given general anaesthesia is no longer practised outside hospitals), dentists are unlikely to find themselves in the dock for professional errors or incompetence.

I mentioned earlier the prosecution for assault of a dentist suspended from practice. The prosecution argued that patients' appar- 
ent consent to her ministrations was invalidated by fraud. They agreed to her examining their mouths, inserting fillings and so on, on the understanding that she was a registered dentist. The Court of Appeal quashed her conviction. They held that her patients consented to the nature of what was done. They knew what was to be done and why. They knew the identity of the accused. They knew her name. Their ignorance of her suspension did not invalidate their consent.

The decision in $\mathrm{R} v$ Richardson ${ }^{16}$ generates lively debate among criminal lawyers. I happen to think it is legally wrong but many eminent colleagues disagree. But did it receive any wide publicity? Not to my knowledge. Imagine if the accused had been a gynaecologist continuing to conduct vaginal examinations after being erased from the medical register? Dentistry (you may be relieved to reflect) does not seem to arouse the same passion as medicine.

The sad and bad reason may be that dental health (oral health) is not valued as it ought to be. Should large parts of England be no go areas for NHS general practice, the tabloids would be baying for Alan Milburn's blood. When medical treatments are unavailable on the NHS, media campaigns asserting our right to healthcare are vigorously pursued. The fragile state of dentistry within the NHS receives too little attention. Perhaps you should invite more publicity - clone your own Lord Winston.

Let me end on a more positive note. I suspect that two other factors may help to insulate dentists from the worst of the adverse effects besetting medicine. At least, in the literature I read, the criticisms of the General Medical Council being too over-indulgent of its malefactors do not seem so prevalent in relation to the General Dental Council. In general dental practice a greater continuity of care (where care is available) still seems common. In medicine, general practitioners are still sued far less often than their hospital counterparts. One factor voiced by potential claimants is that they do not want to take someone they know to court. A mistake may have been made but that mistake (error) is balanced against care and kindness on countless other occasions. General medical practice and general dental practice may be set to change, to become impersonal, based on walk-in centres with much less of a one-to-one service. Dental practice is already often more akin to a business than the traditional model of NHS care. If, or when, that happens not only will patients be ill-served, but doctors (even dentists) will be more likely to be joining the tooth fairy in the dock.
The author acknowledges three dentists: a current MA student, Jyotee Gandhi, whose dissertation inspired part of this lecture and who helped with materials. The author is grateful to Andrew Bridgman, a former MA student, whose knowledge of dental law and ethics has helped immeasurably, and to the author's own dentist, David Kettlewell, for a model of what constitutes good practice.

1. National Audit Office. Handling Clinical Negligence Claims in England, 2001.

2. McCall Smith A. Criminal Negligence and the Incompetent Doctor. Medical Law Review 1993; 1: 336.

3. 1992 (unreported) See Mason J K, McCall Smith A. Law and Medical Ethics. 5th ed. London: Butterworths, 1999, pp241-2.

4. Merry A, McCall Smith A. Errors, Medicine and the Law. Cambridge: Cambridge University Press, 2001, pp18.

5. R v Prentice, R $\vee$ Adomako, R v Holloway [1993] 4 All ER 935, CA

6. Rv Adomako [1995] 1 AC 171, HL.

7. Childs M. Medical manslaughter and corporate liability. Legal Studies 1999 19: 316.

8. http://news.bbc.co.uk/hi/english/uk/scotland/newsid

9. Hampton J. Mens rea. In Paul E F, Miller FD, Paul J (eds) Crime, Culpability and Remedy. Place:Blackwell, 1990.

10. Learning from Bristol. The Report of the Public Inquiry into children's heart surgery at the Bristol Royal Infirmary 1984-1995 CM 5207 (1), 2001.

11. The Bristol Royal Infirmary Interim Report Removal and Retention of Human Material (available at www.bristol-inquiry.org.uk).

12. The Royal Liverpool Children's Inquiry Report HC 12112001.

13. Report of a Census of Organs and Tissue Retained by Pathology Services in England. London: DoH, 2001.

14. Brazier M. Medicine, Patients and the Law. 3rd ed. Place: Penguin, Chapter 19. FOTHCOMING

15. Appleton $v$ Garret [1997] 8 Med LR 75 .

16. R $\vee$ Richardson (Diana) (1998) 43 BMLR 21, CA. 